Anne Bergliot $\emptyset$ yehaug har hovedfag i fysiologi fra Universitetet i Oslo, har erfaring som lærer i naturfag i den videregående skolen og er nå ansatt som høgskolelektor ved Avdeling for lærerutdanning og naturvitenskap, Høgskolen i Hedmark. For tiden er hun i ferd med å avslutte en PhD om naturvitenskapelig kompetanse.

Anne Holt har doktorgrad i fysikk fra Universitetet i Oslo, og jobber nå som førsteamanuensis ved Avdeling for lærerutdanning og naturvitenskap, Høgskolen i Hedmark.

ANNE BERGLIOT ØYEHAUG

Avdeling for lærerutdanning og naturvitenskap, Høgskolen i Hedmark

anne.oyehaug@hihm.no

ANNE HOLT

Avdeling for lærerutdanning og naturvitenskap, Høgskolen i Hedmark

anne.holt@hihm.no

\title{
Sammenhengen mellom naturvitenskapelig produkt og prosess \\ - En studie av dialoger fra utforskende arbeid i naturfag relatert til stoffer og stoffers endringer
}

\begin{abstract}
This paper reports from a study where a teacher and researchers collaborated on designing science teaching promoting scientific inquiry (processes of science) and science content (product of science) for a group of students (age 11 - 13). A wide range of data from students' performance in combining science product and processes were collected during a two year period. Results indicate that students combined product (matter and change of matter) and processes of science (making hypotheses, suggesting research design and evaluating evidence) and that these aspects support each other in science learning. The ability of linking product and process differed among students and varied from one scientific method to the other. To succeed in linking science content and processes of science it is important to scaffold student understanding, like providing templates and asking rich and relevant questions.
\end{abstract}

\section{INNLEDNING}

Naturvitenskapen er både en kunnskapsbase som representerer den nåværende forståelsen av naturen og de prosesser hvor denne kunnskapsbasen stadig utvides, forbedres og revideres (Grandy \& Duschl, 2005). Studier har vist at elevers forståelse og forestillinger om naturvitenskapelige modeller og teorier (produkt) har stor betydning for sentrale prosessaspekter som å generere hypoteser (Echevarria, 2003; Schauble, 1990), designe eksperimenter (Kuhn, Garcia-Mila, Zohar, \& Andersen, 1995) og vurdere evidens (Amsel \& Brock, 1996). Tilsvarende viser studier at utforskende ferdigheter i større grad er påvirket av hva eleven kan om emnet i undersøkelsen enn av deres eksperimentelle ferdigheter eller resonneringsferdigheter (Donnely, 1987; Strang, Daniels, \& Bell, 1991).

Videre viser resultatene fra PISA 2006 at elever i de nordiske landene skårer høyere på å forklare naturvitenskapelige fenomener enn på naturvitenskapelige metodekunnskap. Resultater fra samme PISA-undersøkelse indikerer at det er positiv sammenheng mellom å jobbe utforskende med å tolke og 
bruke evidens og kunne forklare fenomener naturvitenskapelig (Kjærnsli, Lie, Olsen, \& Roe, 2007). I utforskende arbeid ser det også ut til at resonneringsprosesser og begrepsforståelse er gjensidig avhengige av hverandre (Schauble, 1996). Naturfagundervisningen bør derfor både bidra til å utvide elevenes kunnskaper om fenomener i naturen, og hjelpe dem til å utvikle en forståelse for de metodene forskere bruker. Duschl og Grandy (2007) hevder at kunnskapsbygging må skje ved involvering av elevene i alle sider ved den naturvitenskapelige praksisen, som å samle data gjennom observasjon og eksperimenter, representere data, resonnere og argumentere om hva dataene betyr, og anvende kunnskap i nye situasjoner. I Europa oppfordrer en kommisjon nedsatt av EU til mer bruk av utforskende arbeidsmåter for å øke elevers interesse og læring i naturfag (Rocard, 2007).

\section{HENSIKTEN MED UTFORSKENDE ARBEIDSMÅTER}

Lunetta, Hofstein og Clough (2007) hevder at det er en tvetydig bruk av begrepet utforskende arbeidsmåter (inquiry). For eksempel brukes begrepet 'inquiry science teaching' både med referanse til å undervise naturvitenskap som utforskning (hjelpe elever til å forstå hvordan naturvitenskapelig kunnskap utvikles) og å undervise naturvitenskap gjennom utforskning (få studenter til å delta i undersøkelser for å tilegne seg mer meningsfull kunnskap i naturvitenskap). Naturfagundervisning er i varierende rad preget av disse perspektivene. Synspunkter på hva som er hovedhensikten med skolens naturfagopplæring og meninger om hvordan utforskende arbeidsmåter kan bidra til elevers læring vil kunne påvirke lærernes prioriteringer. For eksempel må en ta stilling til om undervisningen hovedsakelig skal ta sikte på å gi elevene kompetanse i fagkunnskap (produkt) eller om det er like viktig at elevene får kompetanse i naturvitenskapelige arbeidsmåter (prosess).

Prosessaspektene som hypotesedanning, eksperimentering, systematiske observasjoner, åpenhet, diskusjoner, kritisk vurdering, argumentasjon, begrunnelser for konklusjoner og formidling defineres ofte som praktisk naturfag (Hodson, 1996). Begrepet praktisk arbeid brukes imidlertid også om rent praktiske aktiviteter, og det har i internasjonal forskning på området vært en utbredt oppfatning at såkalt praktisk arbeid ikke har klart å innfri de mange forventningene (Hofstein \& Lunetta, 1982; Jenkins, 1999). Dette kan blant annet skyldes at det ikke har vært enighet om hva hensikten med praktisk arbeid eller såkalt laboratoriearbeid skulle være. Hodson (1993) legger vekt på at hensikten med laboratorieaktiviteter ikke skal være begrenset til å lære spesifikke vitenskapelige metoder eller bestemte laboratorieteknikker, men at eleven skal bruke metodene og prosedyrene i naturvitenskapen til å undersøke fenomener, løse problemer og forfølge spørsmål og egne interesser. Gunstone (1991) mener at laboratoriearbeid kan være fornuftig for å få elevene til å omstrukturere kunnskapen sin, men samtidig naivt fordi det å utvikle vitenskapelige ideer fra praktiske forsøk ofte er en kompleks prosess. Gunstone og Champagne (1990) foreslår at meningsfull læring i laboratoriet vil kunne skje hvis elevene får nok tid og muligheter for refleksjon. De hevder at elever som oftest ikke har tid og mulighet til refleksjon om sentrale ideer og begreper i laboratoriet siden de vanligvis er involvert i tekniske aktiviteter der de har få muligheter til å uttrykke sin tolkning av undersøkelsen. Watson, Swain og McRobbie (2004) fant at både omfanget og kvaliteten på diskusjonene rundt utforskende arbeid er lave. To case-studier illustrerer også hvor lite effektivt praktisk arbeid alene er, og understreker nødvendigheten av at elevene får diskutere læringsaktivitetene (McRobbie, Roth, \& Lucas, 1997; Scott \& Leach, 1998).

En studie fant at naturfaglærere ofte har problemer med å hjelpe elevene med å stille velfunderte spørsmål, utvikle forskningsdesign, og trekke konklusjoner fra data (Marx, Freeman, Krajcik, \& Blumenfeld, 1998). Eksperimentelt arbeid blir ofte gjort som en ganske begrenset aktivitet som fokuserer på rapportskriving med lite rom for refleksjon (Tiberghien, Veillard, Le Maréchal, Buty, \& Millar, 2001). Dialoger mellom lærere og elever og mellom elever prioriteres sjelden i de ulike fasene av det eksperimentelle arbeidet. Af Geijerstam (2006) fant i en kvalitativ undersøkelse i svensk skole at forsøksrapporten er dominerende tekstpraksis i naturfag, men at rommet for dialogiske prosesser er begrenset. Med dialogiske prosesser mener hun blant annet at teksten har reelle mottakere, at lære- 
ren utvikler og bygger på elevenes tekster, og at ulike uttrykksformer integreres i hverandre. Videre fant Knain (2005) at viktige normer for vitenskapelig arbeid, nemlig å skrive slik at andre kan forstå og gjenta forsøket, blir framholdt som viktig av elever, men at dette i liten grad var operasjonalisert i undervisningen.

\section{DiALOGENS ROLLE I KOBLINGEN MELLOM PRODUKT OG PROSESS}

Viktige elementer for læring som refleksjon og mottakerbevissthet utelates altså ofte i praktisk eksperimentelt arbeid. Det blir ofte hevdet at å lære naturfag handler om å lære å snakke det naturvitenskapelige språket (Lemke, 1990; Wellington \& Osborne, 2001). Elevene bør altså få muligheter til å samtale om naturfaglige fenomener. Det kan imidlertid virke som om elevene vanligvis blir overlatt til seg selv når de skal samtale omkring praktiske øvelser i naturfagtimene (Klette, 2007; Ødegaard \& Arnesen, 2010). Mortimer og Scott (2003) identifiserer en sammenheng mellom måten læreren responderer på elevenes uttalelser og dialogens struktur. Gjennom måten læreren tilrettelegger dialogene på, kan de støtte elevene i å utvikle egne synspunkter basert på naturvitenskapelig kunnskap og evidens. Mercer og Littleton (2007) gjennomførte en intervensjon der elevene ble trent til å bruke språket på en slik måte at de respekterte alle i gruppen, oppmuntret alle til å sette ord på tankene sine og sørget for at alle i gruppa fikk anledning til å snakke. Studien indikerer at trening i slik utforskende snakk bidrar positivt til elevenes naturfagprestasjoner. Det er også tegn som tyder på en omvendt sammenheng; at utforskende snakk, der elevene trener på naturvitenskapelige begreper, bidrar til utvikling av interaktive ferdigheter som å lytte, respondere, stille spørsmål, presentere og vurdere hverandres ideer (Alexander, 2005).

Hensikten med denne studien er å undersøke hvordan elever kobler naturvitenskapelig produkt og prosess. Vi vil ved å analysere dialoger fra utforskende naturfagundervisning relatert til stoffer og stoffers endringer forsøke å svare på følgende forskningsspørsmål:

Hvordan kobler elever naturvitenskapelige teorier og begreper (produkt) og naturvitenskapelige arbeidsmåter (prosess) og hvordan kan støttestrukturer bidra til dette?

\section{Metode}

I denne studien ble elevene i en klasse fulgt fra den våren de gikk i 5. trinn til våren de gikk i 7. trinn. Datamaterialet er hentet fra fire undervisningsperioder, der det på en systematisk måte ble innført ideer om hvordan stoffer er sammensatt og endrer seg. Forskere og lærer samarbeidet om planlegging av undervisningen og forskere var til stede i all undervisning (hver undervisingsperiode besto av fem-seks hele undervisningsdager). Forskerne hadde ansvar for at sentrale naturvitenskapelige begreper og teorier ble ivaretatt og for at utforskende arbeidsmåter ble brukt. Undervisningsplaner ble detaljert utarbeidet for å sikre at de på forhånd definerte intensjonene ble realisert. Læreren hadde ansvaret for gjennomføringen av undervisningen. Forskere var til stede i klasserommet, men da i hovedsak som observatører. De stilte imidlertid spørsmål til elevene både i undervisnings- og intervjusituasjoner. En kan derfor ikke se bort fra at forskerne kan ha påvirket elevenes læring.

Tabell 1 viser hvilke teoretiske elementer (produkt) som ble vektlagt og hvilke ulike naturvitenskapelige arbeidsmåter (prosess) som elevene fikk erfaringer med i de ulike periodene. Undervisningen tok sikte på å engasjere elevene både gjennom små eksperimenter og større utforskende arbeid.

I periode 1 gjorde elevene eksperimenter med luft og vann og deltok i hypotesedanning og tolking av data. I tillegg gjennomførte de en større undersøkelse av sammenhengen mellom det de drakk og det de urinerte. De deltok i utarbeidelse av forskningsspørsmål, hypotesedanning og diskusjon om forskningsdesign. Videre produserte og framstilte elevene data (søylediagram), forsøkte å tolke disse i lys av sentrale naturvitenskapelige teorier og begreper (fordamping) og skrev en forskningsrapport fra undersøkelsen. Periode 2 var også preget av eksperimentell aktivitet med hypotesedanning og 
Tabell 1. En oversikt over hvilke naturvitenskapelige teorier og begreper (produkt) og arbeidsmåter (prosess) elevene ble eksponert for $i$ de fire undervisningsperiodene og hvilke datainnsamlingsmetoder som ble benyttet.

\begin{tabular}{|c|c|c|c|}
\hline Periode & $\begin{array}{l}\text { Naturvitenskapelige teorier og begre- } \\
\text { per om stoffer og stoffers endringer } \\
\text { (produkt) }\end{array}$ & $\begin{array}{l}\text { Naturvitenskape- } \\
\text { lige arbeidsmåter } \\
\text { (prosess) }\end{array}$ & $\begin{array}{l}\text { Datainnsam- } \\
\text { ling }\end{array}$ \\
\hline $\begin{array}{l}\text { Periode } 1 \\
\text { mai - sept } 2009 \\
\text { (vår 5. trinn og } \\
\text { høst 6. trinn) } \\
\text { Partikkel- } \\
\text { modellen }\end{array}$ & $\begin{array}{l}\text { Luft er noe, tar plass og veier noe. } \\
\text { Stoffer (i fast form, væske og gass) } \\
\text { består av partikler. Partiklene oppfører } \\
\text { seg forsjellige i de ulike aggregattil- } \\
\text { standene. Jo raskere partiklene beveger } \\
\text { seg jo høyere temperatur har stoffet. } \\
\text { Trykket i en gass har sammenheng med } \\
\text { hvor ofte og hardt partiklene kolliderer. } \\
\text { I faseoverganger mellom gass, væske } \\
\text { og fast stoff endrer bindingene mellom } \\
\text { partiklene karakter. Stoffet er fortsatt } \\
\text { det samme. }\end{array}$ & $\begin{array}{l}\text { Lage felles forsknings- } \\
\text { spørsmål } \\
\text { Lage hypotese } \\
\text { Delta i utarbeidelse } \\
\text { av forskningsdesign } \\
\text { Produsere data } \\
\text { Tolke data } \\
\text { Skrive rapport }\end{array}$ & $\begin{array}{l}\text { Videoopptak } \\
\text { fra undervis- } \\
\text { ningen } \\
\text { Intervju med } \\
\text { fokuselevene }\end{array}$ \\
\hline $\begin{array}{l}\text { Periode } 2 \\
\text { april - mai } 2010 \\
\text { (vår 6. trinn) } \\
\text { Fotosyntesen } \\
\text { Planter om } \\
\text { våren }\end{array}$ & $\begin{array}{l}\text { Partikler kan være atomer og molekyler. } \\
\text { I fotosyntesen reagerer molekyler med } \\
\text { hverandre og danner nye. Atomene for- } \\
\text { andres ikke i kjemiske reaksjoner. }\end{array}$ & $\begin{array}{l}\text { Lage felles forsknings- } \\
\text { spørsmål } \\
\text { Lage hypotese } \\
\text { Delta i utarbeidelse } \\
\text { av forskningsdesign } \\
\text { Produsere data } \\
\text { Tolke data } \\
\text { Formidle resultater } \\
\text { muntlig }\end{array}$ & $\begin{array}{l}\text { Videoopptak } \\
\text { fra undervis- } \\
\text { ningen } \\
\text { Intervju med } \\
\text { fokuselevene }\end{array}$ \\
\hline $\begin{array}{l}\text { Periode } 3 \\
\text { okt - des } 2010 \\
\text { (høst 7.trinn) } \\
\text { Lyd, Energi og } \\
\text { Elektrisitet }\end{array}$ & $\begin{array}{l}\text { Partiklene overfører lyd og energi. } \\
\text { Elektroner er små partikler som gjør at } \\
\text { det kan gå elektrisk strøm i ledninger. } \\
\text { Varmeenergi er bevegelsesenergi (par- } \\
\text { tikler i bevegelse). }\end{array}$ & $\begin{array}{l}\text { Lage hypotese } \\
\text { Produsere data } \\
\text { Tolke data }\end{array}$ & $\begin{array}{l}\text { Videoopptak } \\
\text { fra undervis- } \\
\text { ningen } \\
\text { Intervju med } \\
\text { fokuselevene }\end{array}$ \\
\hline $\begin{array}{l}\text { Periode } 4 \\
\text { jan - mars } 2011 \\
\text { (vår 7. trinn) } \\
\text { Kjemiske } \\
\text { reaksjoner } \\
\text { Sirkulasjons- } \\
\text { systemet }\end{array}$ & $\begin{array}{l}\text { I kjemiske reaksjoner dannes nye stof- } \\
\text { fer med nye egenskaper. Bindinger } \\
\text { mellom atomene i molekylene brytes } \\
\text { og nye dannes } \\
\text { Oksygenmolekyler inngår i forbren- } \\
\text { ningsreaksjoner. I celleåndingen } \\
\text { reagerer molekyler med hverandre og } \\
\text { danner nye. }\end{array}$ & $\begin{array}{l}\text { Lage forsknings- } \\
\text { spørsmål } \\
\text { Lage hypotese } \\
\text { Utarbeide forsknings- } \\
\text { design } \\
\text { Produsere data } \\
\text { Tolke data } \\
\text { Skrive rapport }\end{array}$ & $\begin{array}{l}\text { Videoopptak } \\
\text { fra undervis- } \\
\text { ningen } \\
\text { Intervju med } \\
\text { fokuselevene }\end{array}$ \\
\hline $\begin{array}{l}\text { april } 2011 \\
\text { Sluttintervju } \\
\text { (vår } 7 . \text { trinn) }\end{array}$ & $\begin{array}{l}\text { Fire case om stoffer og stoffers endrin- } \\
\text { ger: } 1 \text {. Vannets kretsl } \varnothing p, 2 \text {. Brenning av } \\
\text { fyrstikk, 3. Effekten av bloddoping på } \\
\text { sirkulasjonssystemet, } 4 \text {. Følg et blåbær } \\
\text { fra vår til høst }\end{array}$ & $\begin{array}{l}\text { Tolke data } \\
\text { Identifisere fors- } \\
\text { kningsspørsmål } \\
\text { Lage hypoteser } \\
\text { Utarbeide forsknings- } \\
\text { design }\end{array}$ & $\begin{array}{l}\text { Intervju med } \\
\text { fokuselevene }\end{array}$ \\
\hline
\end{tabular}


tolking av data, og elevene gjorde en undersøkelse av hvordan planter om våren er tilpasset til å spire tidlig. Igjen var elevene delaktige i å utarbeide forskningsspørsmål, foreslå hypoteser og diskutere forskningsdesign. Elevene tolket planters bygningstrekk ved å anvende sentrale begreper knyttet til fotosyntesen og presenterte resultatene muntlig. I de to siste periodene (periode 3 og 4 ) laget elevene hypoteser og tolket data mens de deltok i mindre eksperimenter knyttet til temaene lyd, energi, elektrisitet og kjemiske reaksjoner. I periode 4 gjorde de også en større undersøkelse av sirkulasjonssystemet hos mennesker eller dyr der de selv valgte forskningsspørsmål, formulerte hypoteser og foreslo forskningsdesign. Videre fremstilte de data i form av diagrammer og tabeller. I tillegg tolket de dataene fra egne målinger av hjertefrekvens eller lungevolum ved å anvende kunnskaper om forbrenning i cellene. I forskningsrapporten var det et eksplisitt krav at de skulle forklare resultatene i lys av teori om de kjemiske reaksjonene som skjer ved forbrenning i cellene. Elevene fikk altså anledning til å anvende sentrale naturvitenskapelige begreper og teorier om stoffer og stoffers endringer i ulike emner og i ulike situasjoner, samtidig som de lærte naturvitenskapelige arbeidsmåter. Noen arbeidsmåter, som å lage hypoteser, utarbeide forskningsdesign og tolke data ble langt hyppigere brukt enn andre. Siden datamaterialet for disse tre metodene er rikere, vil de bli spesielt vektlagt.

For å få et bilde av hvordan elever kobler produkt og prosess, ble alle sekvenser der fire fokuselever anvendte teorier og begreper om stoffer og stoffers endringer i sammenheng med at de laget hypoteser, foreslo forskningsdesign eller tolket data kodet og analysert. Datamaterialet består av videoopptak av dialoger i klasserommet, intervjuer med fokusgrupper ved slutten av hver undervisningsperiode og individuelle intervjuer med fokuselever ved slutten av 7. trinn (se tabell 1). De fire fokuselevene ble valgt fordi de representerte fire forskjellige elevtyper. De er samtidig representative for hele klassen siden disse elevene som gruppe presterer nær gjennomsnittet (Øyehaug \& Holt, 2012). De to guttene (Thomas og Martin) deltok begge aktivt i diskusjoner i klassen, foretrakk dialoger og eksperimenter, men ikke skriftlig arbeid. En av dem (Thomas) presterte markert bedre enn den andre. Denne eleven var den desidert mest muntlig aktive. En av jentene (Anna) var en typisk høyt presterende elev, som deltok relativt ofte i diskusjoner. Den andre jenta (Elisabeth) deltok derimot lite i diskusjoner i klassen, og foretrakk lesing i større grad enn de andre. Hun presterte faglig noe under gjennomsnittet for klassen.

Ulemper med at mye av datamaterialet er fra klasseromsdialoger er at elevene blir svært ulikt representert (stor forskjell i datamengde fra den muntlig mest aktive sammenlignet med den minst aktive eleven) og at datainnsamlingen ble mindre forutsigbar og skarp. Vi har allikevel valgt å inkludere data fra klasseromsdialoger til tross for de metodiske utfordringene dette medfører, fordi det tilfører studien nyanser gjennom et bredere og mer utfyllende bilde av elevene underveis i læringsprosessene. Dette ville vært vanskelig å fange opp i mer standardiserte og kontrollerte intervjusituasjoner.

Sekvenser der de fire fokuselevene koblet produkt og prosess er sortert etter naturvitenskapelig arbeidsmåte (Lage hypotese, Foreslå forskningsdesign, Tolke data) og kodet for nivå. Det er utviklet nivåkategorier $(1-4)$ både for naturvitenskapelige arbeidsmåter (se tabell 2) og teorier og begreper om stoffer og stoffers endringer (se tabell 3). Kategoriene for stoffer og stoffers endringer ble opprinnelig utviklet for å analysere elevers isolerte produktkompetanse, uavhengig av prosess. Kategoriene er definert slik at jo høyere nivå, jo bedre og mer selvstendig er evnen til å koble ideer på makro- og mikronivå. Når elevene foreslår forskningsdesign og hypoteser, er det ikke alltid naturlig å begrunne på mikronivå. Analysen må sees i lys av dette. 
Tabell 2. Kvalitativ beskrivelse av uttrykt kompetanse i naturvitenskapelige arbeidsmåter (Lage hypotese, Foreslå forskningsdesign, Tolke data).

\begin{tabular}{|l|l|l|l|}
\hline \multicolumn{3}{|c|}{ Naturvitenskapelige arbeidsmåter } \\
\hline 1 & Lage hypotese & Foreslå forskningsdesign & Tolke data \\
& $\begin{array}{l}\text { Har ingen forslag til } \\
\text { hypotese eller forslaget er } \\
\text { helt irrelevant. } \\
\text { Hypotesen begrunnes ikke. }\end{array}$ & $\begin{array}{l}\text { Har ingen eller helt } \\
\text { irrelevante forslag til fors- } \\
\text { kningsdesign. }\end{array}$ & $\begin{array}{l}\text { Kobler i ingen eller svært } \\
\text { liten grad det som } \\
\text { observeres til relevant } \\
\text { kunnskap. }\end{array}$ \\
\hline 2 & $\begin{array}{l}\text { Foreslår hypotese og er vagt } \\
\text { inne på relevant kunnskap i } \\
\text { fors } \varnothing \text { kå å begrunne } \\
\text { hypotesen. }\end{array}$ & $\begin{array}{l}\text { Er inne på relevante un- } \\
\text { ders } \varnothing \text { kelsesmetoder og } \\
\text { anvender til dels relevant } \\
\text { kunnskap. }\end{array}$ & $\begin{array}{l}\text { Kobler i noen grad det som } \\
\text { observeres til relevant } \\
\text { kunnskap. }\end{array}$ \\
\hline 3 & $\begin{array}{l}\text { Foreslår hypotese og klarer } \\
\text { med hjelp å bruke relevant } \\
\text { kunnskap til å begrunne } \\
\text { hypotesen. }\end{array}$ & $\begin{array}{l}\text { Foreslår relevante unders } \varnothing- \\
\text { kelsesmetoder og anvender } \\
\text { med hjelp relevant kunn- } \\
\text { skap. }\end{array}$ & $\begin{array}{l}\text { Kobler det som observeres } \\
\text { til relevant kunnskap, men } \\
\text { med hjelp. }\end{array}$ \\
\hline 4 & $\begin{array}{l}\text { Foreslår hypotese og bruker } \\
\text { selvstendig relevant } \\
\text { kunnskap til å begrunne } \\
\text { hypotesen. }\end{array}$ & $\begin{array}{l}\text { Forslår relevante } \\
\text { unders } \varnothing \text { kelsesmetoder og } \\
\text { anvender selvstendig } \\
\text { relevant kunnskap. }\end{array}$ & $\begin{array}{l}\text { Kobler selvstendig det som } \\
\text { observeres til relevant } \\
\text { kunnskap. }\end{array}$ \\
\hline
\end{tabular}

Tabell 3. Overordnede nivåkategorier for uttrykt produktkompetanse (teorier og begreper om stoffer og stoffers endringer). Hvert nivå er detaljert og kvalitativt beskrevet i vedlegg 1.

\begin{tabular}{|l|l|l|}
\hline Nivå & \multicolumn{2}{|l|}{ Teorier og begreper om stoffer og stoffers endringer } \\
\hline $\mathbf{1}$ & Ingen forståelse & makro og mikro \\
\hline $\mathbf{2}$ & Noe forståelse & makro - ingen evne til å koble ideer på mikro- og makronivå \\
\cline { 3 - 3 } & & mikro - begrenset evne til å koble ideer på mikro- og makronivå \\
\hline 3 & God forståelse & makro - begrenset evne til å koble ideer på mikro- og makronivå \\
\cline { 3 - 3 } & & mikro - begrenset evne til å koble ideer på mikro- og makronivå \\
\hline 4 & God forståelse & makro og mikro - klarer med hjelp å koble ideer på mikro- og makronivå \\
\cline { 3 - 3 } & & makro og mikro - klarer selvstendig å koble ideer på mikro- og makronivå \\
\hline
\end{tabular}




\section{RESULTATER OG ANALYSE}

\section{De fire elevene kobler naturvitenskapelig produkt og prosess}

Figur 1 gir et kvalitativt bilde av hver av de fire elevenes evne til å anvende teorier og begreper om stoffer og stoffers endringer( $\bullet$ i sammenheng med at de henholdsvis lager hypoteser $(\boldsymbol{\Delta})$, foreslår forskningsdesign $(\nabla)$ eller tolker data $(\square)$. Hvert datapunkt angir et gjennomsnitt, beregnet på bakgrunn av alle aktuelle sekvenser fra den bestemte undervisningsperioden. Det varierer hvor ofte de ulike elevene koblet produkt og prosess. Noen datapunkter er derfor basert på kun én sekvens, mens andre er basert på flere (maksimalt fem).
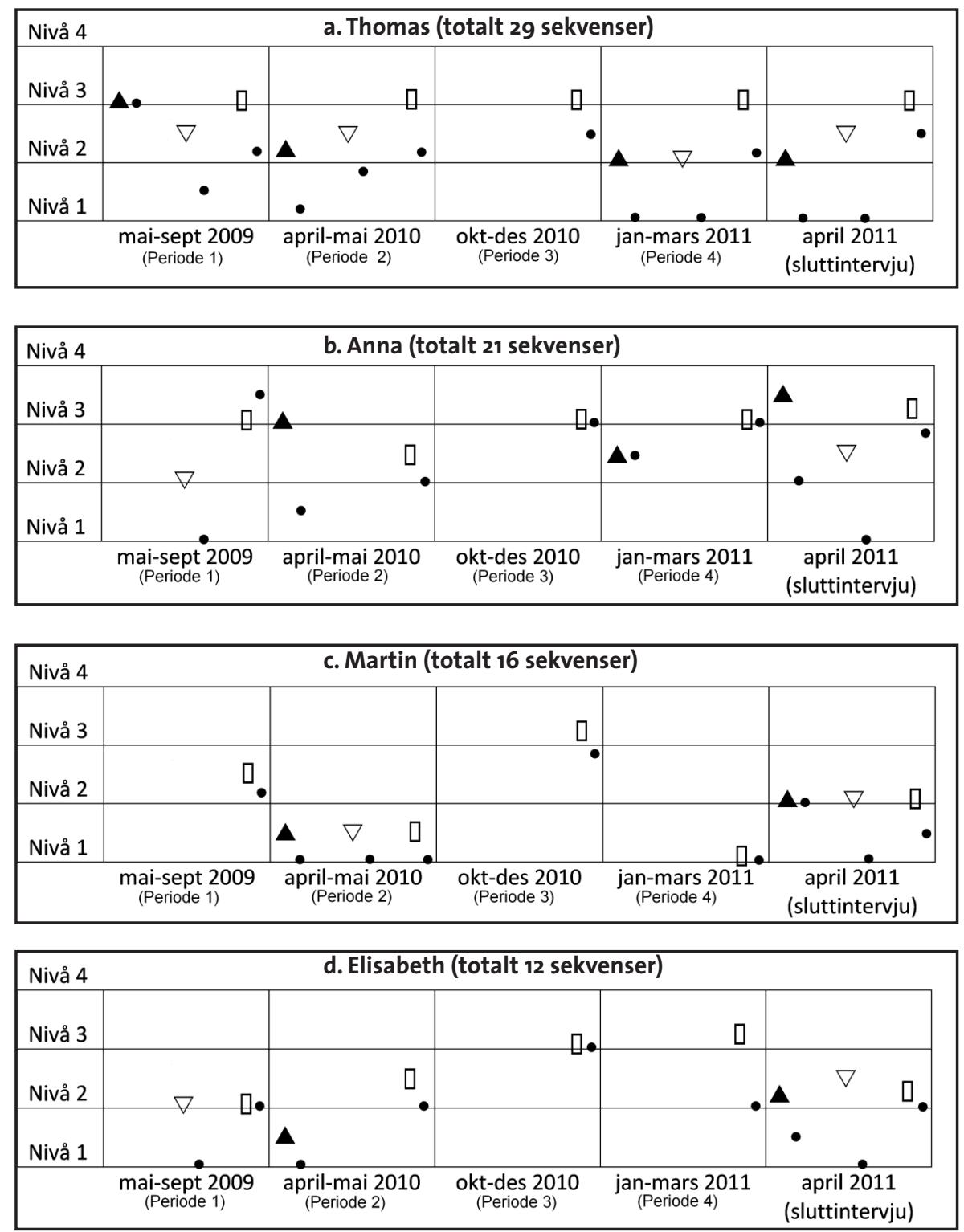

Figur 1: De fire fokuselevene Thomas (a), Anna (b), Martin (c) og Elisabeth (d) kobler naturvitenskapelig produkt $(\bullet)$ og prosess (Lage hypoteser: $\mathbf{\Delta}$; Foreslå forskningsdesign: $\nabla$; Tolke data: $\square$ ). 
I den videre analysen vil vi bruke resultatene i figur 1 til å identifisere generelle trender og ulikheter mellom de fire elevene. Utvalgte sitater og undervisningssituasjoner vil bli analysert for å belyse spesielle trekk ved elevenes faglige utvikling og hvordan støttestrukturer bidro til koblingen mellom produkt og prosess.

\section{Tolke data}

Fokuselevene tolket data i alle undervisningsperiodene. Mange av disse datapunktene er dessuten basert på flere sekvenser. Elevene fikk altså mange anledninger til å tolke data, og de gjorde dette på relativt høyt nivå. De anvendte teorier og begreper om stoffers og stoffers endringer på et høyere nivå når de tolket data enn når de lagde hypoteser og forslo forskningsdesign. I det følgende avsnittet gis eksempler på sitater hvor hver av de fire elevene tolker data.

Thomas tolket data på et stabilt høyt nivå i alle undervisningsperiodene. I periode 1 skulle elevene for eksempel tolke data både fra små eksperimenter (fordamping fra hud og fra vått papir rundt en flaske) og et større utforskende arbeid (måle inntak av væske og urinmengde). Hensikten med de små eksperimentene var å hjelpe elevene til å forstå hva som skjer med noe av vannet vi drikker. På spørsmål fra intervjuer om hvordan de to små eksperimentene kunne bidra til denne forståelsen svarte Thomas:

Vi svetter mer når vi er i aktivitet så det kan også spille inn... [...] så var det andre... å ja det brus... jo det blir kaldere når det fordamper og det betyr altså når vi mennesker svetter.. .det blir kaldere og da bruker en vel mindre...

Intervjuer fulgte opp med å spørre mer inngående hva hvert av eksperimentene viste:

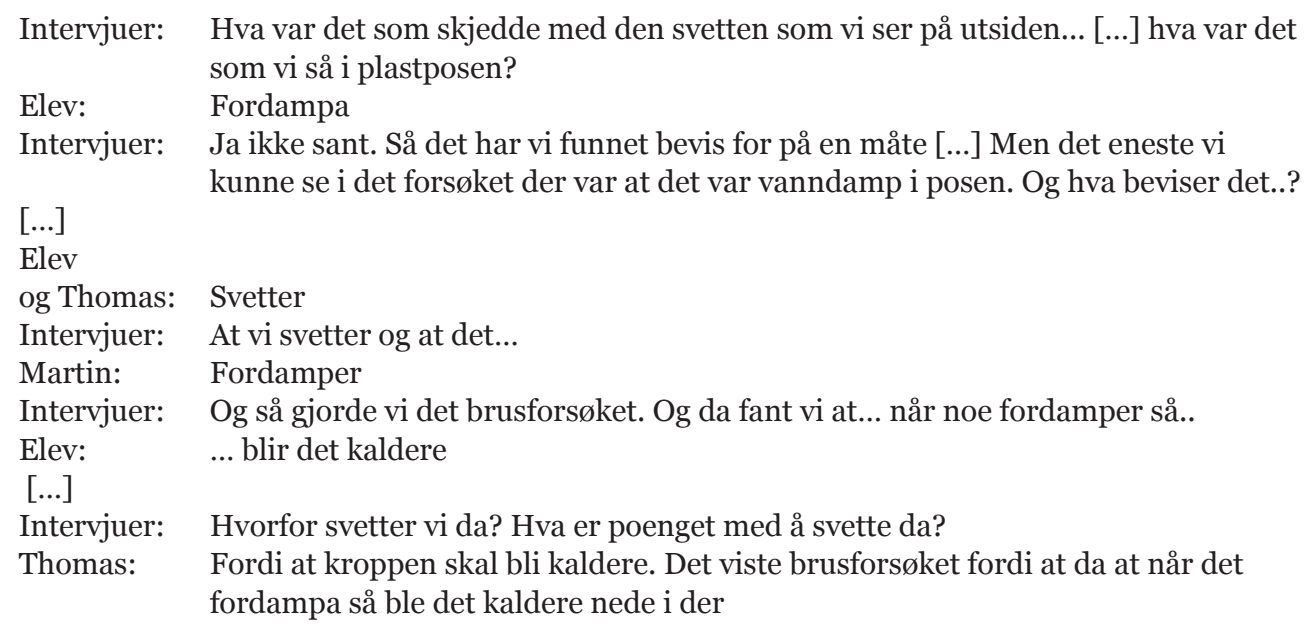

Med mye hjelp, kom Thomas i denne samtalen på et høyt nivå når det gjelder tolkning av data. Han brukte en del relevante naturfaglige begreper i tolkningen, men forklarte ikke hva som skjer i faseoverganger.

I liket med Thomas tolket Anna data på høyt nivå i de ulike periodene, men lykkes noe bedre i å koble teori og begreper om stoffer og stoffer endringer til tolkningene sine. I periode 4 observerte elevene en magnesiumstrimmel som brant, og da Anna ble spurt om hva som hadde skjedd med strimmelen svarte hun: 
Anna: $\quad$ Det går oksygenpartik... molekyler inn i

Lærer: $\quad$ Hva er det som skal skje for at de skal kunne gjøre det?

Anna: $\quad$ Det skapes et hulrom i den... magnesiumatomene..

Hun koblet her relevant naturvitenskapelig kunnskap til det hun nettopp hadde observert.

Martin viste imidlertid svært varierende evne til å tolke data fra den ene situasjonen til den andre. Han tolket data på forholdsvis høyt nivå når han fikk anvende kunnskaper om stoffer (i sammenheng med lukt, lyd og energioverføringer) sammenliknet med når han anvendte kunnskaper om faseoverganger og kjemiske reaksjoner. Ved slutten av periode 3 (7. trinn) brukte Martin kunnskaper om stoff på mikronivå for å forklare sammenhengen mellom en uro over et stearinlys og gardinene over en varmeovn:

Martin: $\quad$ Men jeg kan jo forklare noe annet. Siden der ser vi det! (Gardinene beveger seg). Det er på grunn av varmeovnen..atte dem beveger på seg

Intervjuer: Men hva er det som egentlig skjer..hvis vi tar på oss magiske briller?

Martin: Det er lufta som blir mye varmere og begynner å bevege seg kjempemye og da... og da blir det ikke en sånn derre fast stoff da blir det liksom litt mer sånn derre ... boing... boing (beveger fingrene) liksom mer

Elev: $\quad$ Varmen dytter på partiklene

Martin koblet her selvstendig det som ble observert til relevant kunnskap. Eleven svarte ikke på mikronivå av seg selv, men med oppfølgingsspørsmål fra intervjuer gikk han over til å redegjøre på mikronivå. Selv om ordene manglet, kan man ut fra kroppsspråket og uttrykket "boing... boing" ane at det er partiklenes bevegelse og kollisjoner med gardinen han prøvde å uttrykke. Imidlertid strevde Martin med å koble inn relevant kunnskap når han skulle tolke data om kjemiske reaksjoner og faseoverganger. I sluttintervjuet uttrykte Martin god stoff-forståelse, men svakere forståelse for stoffers endringer.

Gjennom de to årene som studien pågikk, viste Elisabeth en økende evne til å tolke data. I et fokusgruppeintervju ved slutten av periode 4 (7. trinn) ble Elisabeth vist grafen i figur 2, og tolket denne på følgende måte:

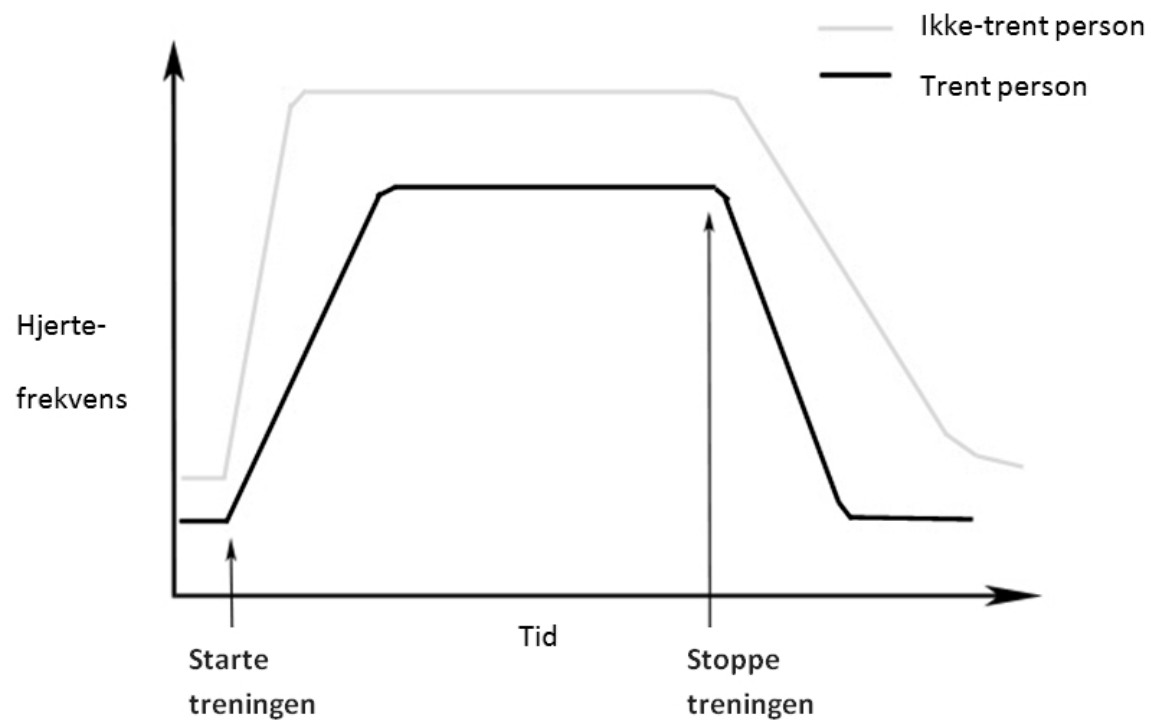

Figur 2: Graf som Elisabeth tolker i periode 4. 
Elisabeth: ...viser hvor stor frekvens hjertet har for en som ikke er så veldig trent og en som er trent, etter at de har løpt i så og så lang tid [...]

Intervjuer: Og hva er forskjellen liksom ... kan du si på en som trener mye..hva er det man kan...

Elisabeth: På en som trener mye så dunker ikke hjertet like fort enn med en som trener

Intervjuer: Nei. Og hva er det med den... Hva viser den skrå... den går litt sånn rett opp og den går skrå... hva betyr det?

Elisabeth: Atte... ååh... atte den som trener, som trener mye... eller det sa jeg jo...

Intervjuer: Ja, men her starter tegninga og her slutter tegninga. Hva er det det viser der... eh... hvor... i forhold til hvor raskt... hvis du tok nå hvert minutt... [...] Eller hvert tiende sekund...

Elisabeth: Atte det går fortere opp... på en måte... frekvensen... hjertet til den som ikke trener så mye i forhold til han som trener så mye

I intervjusituasjonen demonstrerte Elisabeth at hun kunne bruke informasjonen som står på aksene til å tolke at grafen sier noe om sammenhengen mellom hjertefrekvens og hvor godt en person er trent. Med oppfølgingsspørsmål fra intervjuer klarte hun å tolke de forskjellige delene av grafen. Bortsett fra at hun koblet hjertefrekvens (som hun leste av på y-aksen) til hjertet som dunker, brukte Elisabeth kun informasjonen som hun hentet rett ut i fra grafen. Hun fant det ikke nødvendig og ble heller ikke utfordret på å hente fram kunnskap om sirkulasjonssystemet og forbrenning i cellene. I sluttintervjuet viste for øvrig Elisabeth relativt god forståelse for stoffer og stoffers endringer generelt.

\section{Forskningsdesign}

Elevene anvendte bare i noen grad naturvitenskapelige teorier og begreper når de foreslo forskningsdesign. I det følgende avsnittet vil vi belyse dette med sitater fra kun en elev, Thomas.

I et fokusgruppeintervju ved slutten av periode 2 (6. trinn), diskuterte Thomas en mulig metode for å finne ut hvordan vannplanter er tilpasset å gjøre fotosyntese. Han foreslo at man kunne skjært opp stengelen. Intervjuer spurte da om hvilke observasjoner det da kunne være mulig å gjøre, for eksempel hvis de fant at stilken var hul inni. Thomas svarte med å nevne de fleste ingredienser i fotosyntesen (vann, glukose og luft). Imidlertid var han upresis på hva fra lufta som trengtes, og responderte heller ikke mer spesifikt på oppfølgingsspørsmål fra intervjuer.

I sluttintervjuet ble elevene også bedt om å fortelle hvordan de ville gjennomført en undersøkelse for å teste effekten av bloddoping, hvis de hadde hatt tilgang til en gruppe testpersoner. Slik ville Thomas ha gjennomført undersøkelsen:

Thomas: $\quad$ Ehh... hhe... Bloddope en og prøve å utsette han for sykdom for å sjekke om han har noe svekket immunforsvar.. fordi.. for det er de... de hvite blodcellene er for i hvert fall... og så kanskje sjekke hvor fort man kan løpe i forhold til før man var bloddopet og etter man var bloddopet

Intervjuer: Og hvilket utstyr kunne du ha brukt for å finne ut..?

Thomas: $\quad$ En tredemølle for eksempel

Intervjuer: Mmm. Men for å måle ... for å få dataene?

Thomas: $\quad$ En pulsklokke og en tredemølle

Intervjuer: Og hva ville du fătt ved hjelp av en pulsklokke?

Thomas: Pulsen

Thomas trengte noe hjelp til å foreslå relevante målemetoder, og han anvendte noe relevant kunnskap. Han trakk inn immunforsvaret, som kompliserte og først førte han inn på et feilspor. Uten hjelp tok han seg selv inn igjen og foreslo å teste løpeformen til en person før og etter bloddoping. Dette viser at det kan være utfordrende å sortere relevant informasjon fra mindre relevant. De målemeto- 
dene som eleven nevnte må likevel regnes som relevante siden elevene gjennom undervisningen ikke har blitt gjort kjent med metoder/utstyr for måling av prosesser i cellen (på mikronivå). Han brukte i liten grad begreper og teorier om stoffers endringer i forslaget til forskningsdesign. I denne situasjonen er det ikke nødvendigvis relevant å trekke inn celleånding. I mange andre situasjoner hvor det faktisk ville vært naturlig å koble relevant produkt til prosess, utnyttet han ikke sine kunnskaper om naturvitenskapelige teorier og begreper fullt ut. Thomas viste generelt god forståelse for stoffer og stoffers endringer i sluttintervjuet.

\section{Hypotesedanning}

Det kan se ut som de fire elevene bare i noen grad klarte å anvende relevant kunnskap i sammenheng med at de lagde hypoteser. Av figur 1 ser vi at Anna skiller seg positivt ut når det gjelder hypotesedanning. Hun formulerte gjennom alle periodene hypotesene sine etter en bestemt struktur (Jeg tror at... fordi...) som ble vektlagt i undervisningen. Ved hjelp av denne strukturen kan det se ut som hun tidlig fikk som vane å begrunne hypotesene sine, altså å koble produkt til prosess. I periode 2 (6. trinn) foreslo Anna følgende hypotese for hvordan en plante er tilpasset til å leve under vann:

Hmm... jeg tror at planten tar opp luft fra vannet, fordi det er luft i vannet

Selv om strukturen (Jeg tror at ... fordi...) var på plass, gjorde hun her en svak kobling til teorier og begreper. Tilstedeværelsen av luft i vann ble diskutert i forrige periode og elevene hadde nettopp lært om fotosyntesen, men Anna klarte ikke å anvende dette fullt ut da hun skulle begrunne hypotesen sin.

I periode 4 (7. trinn) ble elevene introdusert for kjemiske reaksjoner på mikronivå. I en situasjon satt grupper á fire elever og diskuterte hva de trodde ville skje når en magnesiumstrimmel føres inn i en flamme. Da intervjuer kom bort til elevgruppen for å høre hva de var uenige om sa Anna:

De tror at ehm.. [...] magnesiumstrimmelen brenner, mens vi bare tror at den smelter

Elevene hadde altså ulike forslag til hypoteser. Anna trodde at magnesiumstrimmelen ville smelte, og forsøkte å begrunne sin hypotese ved å beskrive hvordan en eventuell smelting vil foregå. I begrunnelsen for smelting, brukte hun teori om faseoverganger som hun hadde lært i periode 2, men uten å komme inn på mikronivå. Da hun ble utfordret til å begrunne den konkurrerende hypotesen, klarte hun ikke å forklare hva som eventuelt ville skje ved brenning av strimmelen.

I sluttintervjuet fikk Anna et tenkt oppdrag som gikk ut på å teste effekten av bloddoping. Etter at hun hadde identifisert forskningsspørsmålet i en kort tekst som beskrev forskningsoppdraget, ble hun spurt om å lage en hypotese:

Anna: $\quad$ Jeg tror at hvis du får mer tilgang til.. nei får nytt blod og da får du flere røde blod celler og da kan de frakte eh... oksygen og glukose til cellene.. og da ser vi mer for brenning og da jobber du bedre

Sitatet viser at Anna begrunnet hypotesen sin og viste god forståelse for sirkulasjonssystemet og forbrenningsprosessen som skjer i cellene. Lærer trengte ikke å stille utdypende spørsmål fordi eleven selvstendig anvendte relevant kunnskap. Dette resultatet må sees i sammenheng med at elevene en til to måneder i forkant av sluttintervjuet (i periode 4) hadde gjennomført et selvstendig utforskende arbeid i dette temaet. Elevene ble i sluttintervjuet utfordret på å anvende teorier og metoder som var kjent fra tidligere undervisning, men i en ny utforskende kontekst (bloddopings effekt på sirkulasjonssystemet). Måten nivåkategoriene for stoffer og stoffers endringer er definert på medvirket også til at Annas produktkompetanse ble kodet som relativt lav. Selv om hun i sluttintervjuet viste god forståelse for stoffer og stoffers endringer generelt, var det ikke naturlig for henne å bringe inn detaljer om kjemiske reaksjoner i cellen da hun begrunnet hypotesen sin. 


\section{St $\varnothing$ ttestrukturenes betydning for kobling mellom naturvitenskapelig produkt og prosess}

Sitatene viser at måten lærer eller intervjuer stilte spørsmål på bidro positivt til at elevene koblet naturvitenskapelig produkt og prosess. I eksemplet under (fra periode 3) diskuterer elevene elektrisk strøm. Her sees hvordan intervjuer stilte spørsmål som ledet elevene til å forklare sammenhengen mellom at lampa lyser (observasjon) og hvordan elektronene beveger seg i ledningen (tolkning av data på mikronivå).

Intervjuer: Så hvordan er det de oppfører seg hvis vi hadde... tenker oss

Thomas: $\quad$ at vi hadde magiske briller? Hvordan hadder på hverandre (viser med hånda)

I forbindelse med alle de utforskende arbeidene ble det gjort ulike grep som alle hadde til hensikt å hjelpe elevene med å anvende det de hadde lært om stoffer og stoffers endringer. Det ble for eksempel utviklet maler til rapporter, som i periode 1 blant annet inneholdt følgende forslag til måte å formulere resultatet på: Resultatet var... og et forslag på forklaring kan være... (her bør du bruke det som står i teoridelen). Lærer spilte også en aktiv rolle med å understreke koblingen mellom produkt og prosess i det hun innledet arbeidet med rapportskrivingen:

Lærer: $\quad$ Det er konklusjonen. Og så står det videre ”Denne konklusjonen kan vi trekke fordi...": Hvorfor kan vi si det at vi tisser mindre enn vi drikker?[...] hvordan kan vi argumentere, hvilke bevis på en måte har vi for å si det?

På lignende måte ble støttestrukturen (Jeg tror at... fordi...) innført for å hjelpe elevene med å formulere begrunnede hypoteser.

\section{DisKuSJON}

\section{Kobling mellom naturvitenskapelig produkt og prosess}

Alle de fire fokuselevene i denne studien koblet naturvitenskapens teorier og begreper med naturvitenskapens arbeidsmåter (laget hypoteser, foreslo forskningsdesign og tolket data). Elevene har fått mange muligheter til å samtale om naturfaglige fenomener, nettopp det som Lemke (1990) og Wellington \& Osborne (2001) hevder er det samme som å lære naturfag. Det kan derfor se ut til at undervisningen har klart å integrere resonneringsprosesser, eksperimentelt arbeid og begrepsforståelse, som Lehrer, Scauble, Strom og Pligge (2001) hevder er gjensidig avhengige av hverandre. Videre ser det ut til at elevenes evne til å lage hypoteser, å foreslå forskningsdesign og å tolke data er avhengig av forståelse for teorier og begreper som er relevante i den aktuelle undersøkelsen. De brukte naturvitenskapelige begreper og teorier i ulik grad ved utøvelsen av de tre arbeidsmåtene.

Elevene fikk rikelige anledninger til å tolke data i både små og store undersøkelser. De små undersøkelsene ble gjennomført i nær tilknytning til undervisning om relevante begreper og teorier om stoffer og stoffers endring. Når elevene tolket data fra disse forsøkene brukte de ofte relevante naturvitenskapelige begreper og teorier på mikronivå (jfr. Martin om lukt og energioverføring). Dette er i tråd med Amsel \& Brock (1996) som fant at elevers forståelse og forestillinger om naturvitenskapelige modeller og teorier (produkt) har stor betydning for elevenes ferdigheter i å vurdere evidens.

På en liknende måte så det ut til at hypotesedanningen (prosess) kalte fram relevante naturvitenskapelige teorier og begreper (produkt) som elevene var blitt kjent med i undervisningen. Echevarria (2003) og Schauble (1990) fant også at elevers produktforståelse i stor grad bidro til deres ferdigheter i å generere hypoteser. Imidlertid anvendte Thomas bare i noen grad relevante naturvitenskapelige begreper og teorier når han foreslo forskningsdesign. En utfordring når elever skal velge undersøkelsesmetoder kan for eksempel være å sortere relevant informasjon fra mindre relevant (jfr. Thomas om immunforsvar). Videre er det sannsynlig at elevene ikke alltid opplever at det er nødvendig å gi 
detaljerte faglige redegjørelser, og at dette kan være noe av årsaken til at elevene ikke tar ut hele potensialet sitt når det gjelder å anvende teorier og begreper (produkt) både når de foreslår hypoteser og forskningsdesign (prosess). Det ser også ut til at elevene ikke nødvendigvis blir mer kompetente selv om de har gjentatt og diskutert de samme naturvitenskapelige arbeidsmåtene flere ganger i ulike kontekster. Hver kontekst oppleves nettopp som annerledes, fordi elevene må anvende nye teorier og begreper. Funnene er i tråd med studier som viser at ferdigheter i naturvitenskapelige arbeidsmåter i stor grad er påvirket av forståelse for naturvitenskapelige teorier og begreper (Donnely, 1987; Strang et al., 1991).

\section{Støttestrukturer som fremmer koblingen mellom produkt og prosess}

Elevene i denne studien gjennomførte tre relativt omfattende utforskende arbeid (se tabell 1). De utforskende arbeidene var i stor grad forankret i og tok utgangspunkt i bestemte naturvitenskapelige fenomener som ble undervist samtidig. Hmelo-Silver, Duncan og Chinn (2007) hevder at vellykkede prosjekter med utforskende arbeidsmåter inneholder rammer for arbeidet og støttestrukturer, men at lærerens styring gjøres på en annen måte enn i tradisjonell undervisning. I en tidligere intervensjonsstudie med utforskende arbeidsmåter ble slike støttestrukturer benyttet, og det ble rapportert at deltakende elever presterte bedre på tester i naturfag enn en kontrollgruppe (Geier et al., 2008). I vår studie var det omfattende bruk av støttestrukturer og det ble hele tiden lagt vekt på koblingen til de naturvitenskaplige fenomenene. Elevene ble for eksempel ofte bedt om å begrunne tolkningene sine i de små eksperimentene de gjennomførte. Imidlertid kan det se ut til at elevene trengte tydeligere støttestrukturer for å koble produkt og prosess i større utforskende arbeid. En slik støttestruktur var for eksempel at elevene fikk beskjed om at teoridelen var nødvendig for å underbygge de forsøkene de faktisk hadde gjort. Det ser ut til at strukturene (Jeg tror at... fordi...) og (Resultatet var... og et forslag på forklaring kan være...) bidro til at elevene begrunnet hypotesene og tolkningene sine, altså at de koblet produkt til prosess. Når det gjelder forskningsdesign ble ikke slike støttestrukturer vektlagt i samme grad. Både lærer og intervjuere kunne stilt flere oppfølgingsspørsmål for å få fram begrunnelser for valg av forskningsdesign.

Koblingen mellom produkt og prosess og kvaliteten på denne avhenger i stor grad av måten de voksne stiller spørsmål på. Mortimer og Scott (2003) beskriver læring som både individuell meningsskaping hvor man rekonstruerer gamle og nye ideer, og dialogisk meningsskaping hvor ideer gis et språk i en sosial sammenheng. De hevder også at måten læreren tilrettelegger dialogene på, kan støtte elevene i å utvikle egne synspunkter basert på naturvitenskapelig evidens. I vår studie viser alle sitatene eksempler på samhandling av ulik art. Det foregikk mange slike dialoger i klasserommet, for eksempel før og etter eksperimenter. Det ble altså tilrettelagt for samtale omkring praktiske øvelser, i motsetning til hva andre studier har vist er vanlig i norske klasserom (Klette, 2007, Ødegaard og Arnesen, 2010).

\section{Implikasjoner for undervisning}

I denne studien ser vi at elevenes forståelse av naturvitenskapens produkt kan påvirke elevenes kompetanse i naturvitenskapens prosesser i positiv retning. Det er også slik at utforskende arbeidsmåter vil kunne gi elevene flere anledninger til å utvikle forståelse for naturvitenskapelige teorier og begreper. Læring av naturvitenskapelig produkt og prosess ved praktisk arbeid er avhengig av måten det ledes på. Lærer må tilrettelegge for situasjoner som får elevene til å koble naturvitenskapelige arbeidsmåter og naturvitenskapelige teorier og begreper. Det bør for eksempel gis støttestrukturer som hjelper elevene til å begrunne hypoteser og gjøre tolkninger som er forankret i relevant teori. I forbindelse med store og små undersøkelser er det viktig at lærer stiller spørsmål for å få elevene til å anvende relevante naturvitenskapelige begreper og teorier. 


\section{REFERANSER}

af Geijerstam, Å. (2006). Att skriva i naturorienterande ämnen i skolan. Uppsala: Acta Universitas Upsaliensis, Studia Linguistica Upsaliensia, 3.

Alexander, R. (2005). Towards Dialogic Teaching. York: Dialogos.

Amsel, E., \& Brock, S. (1996). The development of ecvidence evaluation skills. Cognitive Development, 11, 523-550.

Donnely, J. F. (1987). Fifteen-year-old pupils' variable handling perfomances in the context of scientific investigations. Research in Science and Technological Education, 5(2), 135-147.

Duschl, R. A., \& Grandy, R. E. (2007). Teaching scientific inquiry: recommendations for research and implementation. Rotterdam: Sense Publishers.

Echevarria, M. (2003). Anomalies as a catalyst for middle school student's knowledge construction and scientific reasoning during science inquiry. Journal of Educational Psychology, 95, 357-374.

Geier, R., Blumenfeld, P. C., Marx, R. W., Krajcik, J. S., Fishman, B., Soloway, E., \& Clay-Chambers, J. (2008). Standardized Test Outcomes for Students Engaged in Inquiry-Based Science Curricula in the Context of Urban Reform. Journal of Research in Science Teaching, 45(8), 922-939.

Grandy, R. E., \& Duschl, R. A. (2005). Reconsidering the character and role of inquiry in school science: Analysis of a conference. Paper presented at the International HPS and Science Teaching Group, Leeds, England.

Gunstone, R. F. (1991). Reconstructing theory from practical experience. In B. E. Woolnough (Ed.), Practical science (pp. 67-77). Milton Keynes: Open University Press.

Gunstone, R. F., \& Champagne, A. B. (1990). Promoting conceptual change in the laboratory. In E. Hegarty-Hazel (Ed.), The student laboratory and the science curriculum (pp. 159-182). London: Routledge.

Hmelo-Silver, C. E., Duncan, R. G., \& Chinn, C. A. (2007). Scaffolding and achievement in problembased and inquiry learning: A response to Kirschner, Sweller and Clark. Educational Psychologist, 42(2), 99-107.

Hodson, D. (1993). Re-thinking old ways: towards a more critical approach to practical work in school science. Studies in Science Education, 22, 85-142.

Hodson, D. (1996). Practical work in school science: exploring some directions for change. International Journal of Science Education, 18(7), 755-760.

Hofstein, A., \& Lunetta, V. N. (1982). The role of the laboratory in science teaching: Neglected aspects of research. Review of Educational Research, 52(2), 201-217.

Jenkins, E. W. (1999). Practical work in scool science - some questions to be answered. In J. Leach \& A. C. Paulsen (Eds.), Practical work in science education. Roskilde: Roskilde University Press.

Kjærnsli, M., Lie, S., Olsen, R. V., \& Roe, A. (2007). Resultater for naturfag, I: Tid for tunge løft. Norske elevers kompetanse i naturfag, lesing og matematikk i PISA 2006. (pp. 57 -76). Oslo: Universitetsforlaget.

Klette, K. (2007). Trends in Research on Teaching and Learning in Schools: didactics meets classroom studies. European Educational Research Journal 6(2), 147-161.

Knain, E. (2005). Identity \& genre literacy in high scool students' experiemtal reports. International Journal of Science Education, 25(5), 607-624.

Kuhn, D., Garcia-Mila, M., Zohar, A., \& Andersen, C. (1995). Strategies of knowledge acquisition. Monographs of the Society for Research in Child Development Serial No. 245(60 (4)).

Lehrer, R., Schauble, L., Strom, D., \& Pligge, M. (2001). Similarity of form and substance: Modeling material kind. In I. D. Klahr \& S. Carer (Eds.), Cognition and instruction: 25 years of progress (pp. 39-74). NJ: Mahwah: Lawrence Erlbaum Associates.

Lemke, J. L. (1990). Talking science: Language, learning and values. Norwood, NJ: Ablex Publishing Corporation.

Lunetta, V. N., Hofstein, A., \& Clough, M. (2007). Learning and teaching in the school science laboratory: an analysis of research, theory, and practice. In N. Lederman \& S. Abel (Eds.), Handbook of research on science education (pp. 393-441). Mahwah, NJ: Lawrence Erlbaum. 
Marx, R. W., Freeman, J. G., Krajcik, J. S., \& Blumenfeld, P. C. (1998). Professional development of science teachers. In B. J. Fraser \& K. G. Tobin (Eds.), International handbook of science education (pp. 667-680). Dordrecht: Kluwer.

McRobbie, C., Roth, W. M., \& Lucas, K. B. (1997). Multiple learning environments in a physics classroom. International Journal of Science Education, 27, 333-342.

Mercer, N., \& Littleton, K. (2007). Dialogue and the Development og Children's Thinking. London: Routledge.

Mortimer, E. F., \& Scott, P. H. (2003). Meaning Making in Secondary Science Classrooms. Maidenhead, Philadelphia: Open University Press.

Rocard, M. p. (2007). Science education now: A renewed pedagogy for the future of Europe. Luxembourg: Office for Official Publications of the European Communities.

Schauble, L. (1990). Belief revision in children: The role of prior knowledge and strategies for generating evidence. Journal of Experimental Child Psychology, 49(1), 102 - 119.

Schauble, L. (1996). The development of scientific reasoning in knowledge-rich contexts. Developmental Psychology, 32(1), 102 - 119.

Scott, P., \& Leach, J. (1998). Learning science concepts in the secondary science classroom. In M. Ratcliffe (Ed.), ASE Guide to Secondary Science Education (pp. 59-66). Cheltenham: Stanley Thornes.

Strang, S., Daniels, S., \& Bell, J. (1991). Assessment Matters No.6: Planning and Carrying out Investigations. London: School Examinations and Assessment Council.

Tiberghien, A., Veillard, L., Le Maréchal, J. F., Buty, C., \& Millar, R. (2001). An analysis of labwork tasks used in science teaching at upper secondary school and university levels inseveral european countries. Science Education, 85, 483-508.

Watson, J. R., Swain, J. R., \& McRobbie, C. (2004). Students' discussions in practical scientific inquiries. International Journal of Science Education 32(5), 487-502.

Wellington, J., \& Osborne, J. (2001). Language and Literacy in Science Education. Buckingham: PA: Open University Press.

Ødegaard, M., \& Arnesen, N. (2010). Hva skjer i naturfagklasserommet? Resultater fra en videobasert klasseromsstudie. NorDiNa, 6(1), 16-32.

Øyehaug, A. B., \& Holt, A. (2013). Students' understanding of nature of matter and chemical reactions - a longitudinal study of conceptual restructuring. Antatt for publisering i Chemistry Education Research and Practice. 


\section{Vedlegg 1}

\begin{tabular}{|c|c|c|c|}
\hline LEVEL & MATTER & CHEMICAL REACTIONS & PHASE TRANSITIONS \\
\hline 1 & \multicolumn{3}{|c|}{ No understanding (macro and sub-micro) } \\
\hline & $\begin{array}{l}\text { The student shows none or very } \\
\text { vague macroscopic and sub- } \\
\text { microscopic understanding of } \\
\text { matter. One or no concepts of } \\
\text { matter (such as air, gas, liquid, } \\
\text { solid) or chemical symbols } \\
\text { (such as } \mathrm{H}_{2} \mathrm{O} \text { ) are mentioned. }\end{array}$ & $\begin{array}{l}\text { The student shows none or very } \\
\text { vague macroscopic and sub- } \\
\text { microscopic understanding of } \\
\text { chemical reactions. One or no } \\
\text { substances or chemical symbols } \\
\text { (such as } \mathrm{H}_{2} \mathrm{O} \text { ) involved in the } \\
\text { reaction are mentioned. }\end{array}$ & $\begin{array}{l}\text { The student shows none or very } \\
\text { vague macroscopic and sub- } \\
\text { microscopic understanding of } \\
\text { phase transitions. The substance } \\
\text { involved in the phase transition is } \\
\text { mentioned. }\end{array}$ \\
\hline & \multicolumn{3}{|c|}{ Some understanding (macro) - no ability to link sub-microscopic and macroscopic ideas } \\
\hline & $\begin{array}{l}\text { The student mentions some } \\
\text { macroscopic properties of } \\
\text { matter, with no ability to link } \\
\text { this to sub-microscopic ideas. } \\
\text { Uses phrases such as hot air will } \\
\text { rise, without linking it to the } \\
\text { particles' behaviour in gases. }\end{array}$ & $\begin{array}{l}\text { The student mentions some of the } \\
\text { substances involved in the actual } \\
\text { chemical reaction, but shows no } \\
\text { understanding of how matter } \\
\text { changes in the reaction (i.e. no } \\
\text { ability to link this to sub- } \\
\text { microscopic ideas). }\end{array}$ & $\begin{array}{l}\text { The student mentions the states of } \\
\text { matter involved in the phase } \\
\text { transition, but shows no } \\
\text { understanding of how the } \\
\text { transition takes place (i.e. no } \\
\text { ability to link this to sub- } \\
\text { microscopic ideas). }\end{array}$ \\
\hline 2 & \multicolumn{3}{|c|}{$\begin{array}{c}\text { Some understanding (sub-micro) - limited ability to link sub-microscopic and macroscopic } \\
\text { ideas }\end{array}$} \\
\hline & $\begin{array}{l}\text { The student uses concepts such } \\
\text { as } \mathrm{H}_{2} \mathrm{O}, \mathrm{O}_{2} \text {, particle, molecule or } \\
\text { atom, but expresses only a } \\
\text { vague understanding of matter } \\
\text { consisting of smaller units. } \\
\text { Shows no ability to link these } \\
\text { sub-microscopic ideas to } \\
\text { macroscopic properties of } \\
\text { matter. }\end{array}$ & $\begin{array}{l}\text { The student mentions some of the } \\
\text { molecules involved in the actual } \\
\text { chemical reaction, but expresses } \\
\text { only a vague understanding of how } \\
\text { these molecules change in the } \\
\text { reaction. Does not link the sub- } \\
\text { microscopic concepts about } \\
\text { chemical reactions to macroscopic } \\
\text { ideas, like conservation of mass or } \\
\text { visual indication that a chemical } \\
\text { reaction has taken place. }\end{array}$ & $\begin{array}{l}\text { The student mentions the } \\
\text { molecule involved in the actual } \\
\text { phase transition, but expresses } \\
\text { only a vague understanding of } \\
\text { how the inter-connection between } \\
\text { molecules changes during phase } \\
\text { transition. Does not link the sub- } \\
\text { microscopic concepts about phase } \\
\text { transitions to macroscopic ideas, } \\
\text { like conservation of mass or visual } \\
\text { indications that the matter of } \\
\text { state has changed. }\end{array}$ \\
\hline & \multicolumn{3}{|c|}{ Good understanding (macro) - limited ability to link sub-microscopic and macroscopic ideas } \\
\hline & $\begin{array}{l}\text { The student shows through } \\
\text { his/her use of concepts such as } \\
\text { temperature, pressure, mass, } \\
\text { volume and state that (s)he has } \\
\text { a clear understanding of } \\
\text { matter, but shows limited } \\
\text { ability to link macroscopic } \\
\text { properties to sub-microscopic } \\
\text { ideas. }\end{array}$ & $\begin{array}{l}\text { The student mentions most of the } \\
\text { relevant substances in the actual } \\
\text { chemical reaction and expresses } \\
\text { understanding of how matter } \\
\text { changes in the reaction. The } \\
\text { student shows limited ability to } \\
\text { link macroscopic properties to sub- } \\
\text { microscopic ideas. }\end{array}$ & $\begin{array}{l}\text { The student mentions the } \\
\text { substance involved in the actual } \\
\text { phase transition and how the state } \\
\text { of matter changes but the } \\
\text { substance remains the same. The } \\
\text { student shows limited ability to } \\
\text { link macroscopic properties to } \\
\text { sub-microscopic ideas. }\end{array}$ \\
\hline
\end{tabular}




\begin{tabular}{|c|c|c|c|}
\hline \multirow[t]{2}{*}{3} & \multicolumn{3}{|c|}{$\begin{array}{l}\text { Good understanding (sub-micro) - limited ability to link sub-microscopic and macroscopic } \\
\text { ideas }\end{array}$} \\
\hline & $\begin{array}{l}\text { The student uses concepts such } \\
\text { as } \mathrm{H}_{2} \mathrm{O}, \mathrm{O}_{2}, \text { particle, molecule or } \\
\text { atom, and expresses a clear } \\
\text { understanding of matter } \\
\text { consisting of smaller units and } \\
\text { how these smaller units move } \\
\text { and are inter-connected in } \\
\text { different states of matter. The } \\
\text { student shows limited ability to } \\
\text { link these sub-microscopic } \\
\text { ideas to macroscopic properties } \\
\text { of matter, for instance pressure } \\
\text { and temperature. }\end{array}$ & $\begin{array}{l}\text { The student mentions most of the } \\
\text { relevant molecules and symbols in } \\
\text { the actual chemical reaction, and } \\
\text { expresses sub-microscopic } \\
\text { understanding of how bonds } \\
\text { between atoms are broken and } \\
\text { formed in this reaction. The } \\
\text { student shows limited ability to } \\
\text { link these sub-microscopic ideas to } \\
\text { macroscopic ideas of chemical } \\
\text { reactions. }\end{array}$ & $\begin{array}{l}\text { The student mentions the } \\
\text { molecule involved in the actual } \\
\text { phase transition, and expresses } \\
\text { sub-microscopic understanding of } \\
\text { how the bonds between } \\
\text { molecules change. The student } \\
\text { shows limited ability to link these } \\
\text { sub-microscopic ideas to } \\
\text { macroscopic ideas of phase } \\
\text { transition. }\end{array}$ \\
\hline & \multicolumn{3}{|c|}{$\begin{array}{l}\text { Good understanding (macro and sub-micro) - ability to link sub-microscopic and macroscopic } \\
\text { ideas (needs scaffolding) }\end{array}$} \\
\hline & $\begin{array}{l}\text { The student has a clear } \\
\text { understanding of matter } \\
\text { consisting of smaller units. At } \\
\text { the same time (s)he uses } \\
\text { concepts such as mass, volume, } \\
\text { temperature and pressure and } \\
\text { shows the ability to link sub- } \\
\text { microscopic ideas to these } \\
\text { macroscopic properties, for } \\
\text { example that the pressure } \\
\text { exerted by a gas is due to the } \\
\text { collective impact of the } \\
\text { particles on the walls of the } \\
\text { container. However, the } \\
\text { content is not expressed } \\
\text { independently. }\end{array}$ & $\begin{array}{l}\text { The student mentions most of the } \\
\text { relevant substances as well as } \\
\text { molecules involved in the actual } \\
\text { chemical reaction. The student has } \\
\text { a clear understanding of how } \\
\text { matter changes in the reaction on } \\
\text { a macroscopic level as well as on a } \\
\text { sub-microscopic level. The student } \\
\text { shows ability to link sub- } \\
\text { microscopic ideas to macroscopic } \\
\text { ideas of chemical reactions (for } \\
\text { example that conservation of mass } \\
\text { implies that matter is neither } \\
\text { created nor destroyed, i.e. the } \\
\text { atoms remain the same). However, } \\
\text { the content is not expressed } \\
\text { independently. }\end{array}$ & $\begin{array}{l}\text { The student mentions the relevant } \\
\text { substance as well as the type of } \\
\text { molecule involved in the actual } \\
\text { phase transition. The student has } \\
\text { a clear understanding of how the } \\
\text { state of matter changes on a } \\
\text { macroscopic level as well as on a } \\
\text { sub-microscopic level. The student } \\
\text { shows ability to link sub- } \\
\text { microscopic ideas to macroscopic } \\
\text { ideas of phase transitions (for } \\
\text { example that conservation of mass } \\
\text { implies that matter is neither } \\
\text { created nor destroyed, and that } \\
\text { the atoms as well as the molecules } \\
\text { remain the same). However, the } \\
\text { content is not expressed } \\
\text { independently. }\end{array}$ \\
\hline \multirow[t]{2}{*}{4} & \multicolumn{3}{|c|}{$\begin{array}{l}\text { Good understanding (macro and sub-micro) - ability to link sub-microscopic and macroscopic } \\
\text { ideas (needs no scaffolding) }\end{array}$} \\
\hline & $\begin{array}{l}\text { The student has a clear } \\
\text { understanding of matter } \\
\text { consisting of smaller units. At } \\
\text { the same time (s)he uses } \\
\text { concepts such as mass, volume, } \\
\text { temperature and pressure and } \\
\text { shows the ability to link sub- } \\
\text { microscopic ideas to these } \\
\text { macroscopic properties (for } \\
\text { example that atoms are the } \\
\text { same even if the substance, } \\
\text { which the atom is part of, may } \\
\text { change in various ways). } \\
\text { Moreover, the content is } \\
\text { expressed independently. }\end{array}$ & $\begin{array}{l}\text { The student mentions most of the } \\
\text { relevant substances as well as } \\
\text { molecules involved the actual } \\
\text { chemical reaction. The student } \\
\text { expresses understanding of how } \\
\text { matter changes in the reaction on } \\
\text { a macroscopic level as well as on a } \\
\text { sub-microscopic level. The student } \\
\text { shows ability to link sub- } \\
\text { microscopic ideas to macroscopic } \\
\text { ideas of chemical reactions, for } \\
\text { example that conservation of mass } \\
\text { implies that matter is neither } \\
\text { created nor destroyed, i.e. the } \\
\text { atoms remain the same. } \\
\text { Moreover, the content is } \\
\text { expressed independently. }\end{array}$ & $\begin{array}{l}\text { The student mentions the relevant } \\
\text { substance as well as the type of } \\
\text { molecule involved in the actual } \\
\text { phase transition. The student has } \\
\text { a clear understanding of how the } \\
\text { state of matter changes on a } \\
\text { macroscopic level as well as on a } \\
\text { sub-microscopic level. The student } \\
\text { shows ability to link sub- } \\
\text { microscopic ideas to macroscopic } \\
\text { ideas of phase transitions, for } \\
\text { example that conservation of mass } \\
\text { implies that matter is neither } \\
\text { created nor destroyed, i.e. the } \\
\text { atoms as well as the molecules } \\
\text { remain the same. Moreover, the } \\
\text { content is expressed } \\
\text { independently. }\end{array}$ \\
\hline
\end{tabular}

